\title{
Academic Performance and Nutritional Status - A Case Study on College Students in North Tripura.
}

\author{
Dr. Santanu Ghosh, ${ }^{1}$ Dr. Sambhunath Rakshit ${ }^{2}$, Dr. Manik Bhattacharya ${ }^{3}$ \\ 1 (Department of Human Physiology/Government Degree College, Dharmanagar, North Tripura.) \\ 2 (Principal/Government Degree College, Dharmanagar, North Tripura.) \\ 3 (Department of Economics/Government Degree College, Dharmanagar, North Tripura.)
}

\begin{abstract}
The development of any nation or community depends largely on the quality of education of such a nation. Understanding the nature of the causal relationship between health and education is important to determine the exact relation between them. The mechanism by which health and nutrition influence educational achievement is not well established, but poor health and malnutrition in early childhood may affect cognitive abilities, necessary for learning process and consequently educational achievement. This study shows that that, firstly, the tribal students have lower BMI values than their nontribal counterparts which may be due to dietary differences - tribal students have less access to convenience foods and as such may have less consumption of these type of empty calorie containing foods. Also the academic achievements of tribal students are a little lower than their nontribal counterparts which again comes out in the regression and negative correlation of BMI with academic achievement.
\end{abstract}

\section{Introduction}

The development of any nation or community depends largely on the quality of education of such a nation. It is generally believed that the basis for any true development must commence with the development of human resources [1] It has been argued that health is an important factor for academic achievement at school [2,3] and in higher education [4]. Consequently, in the context of universities or colleges, promoting the health and well-being of all members means promoting effective learning [5]. A systematic literature review to examine whether school health programmes improved academic success provided positive evidence for at least some programmes [6]. Similarly, another review showed positive associations between parameters of health (e.g., school-based physical activities) and academic outcomes/performance [6]. Chronic malnutrition experienced during early life inhibits growth, retards mental development, and reduces motivation and energy level, causing a reduction of educational attainments and delay in school entry [2]. Understanding the nature of the causal relationship between health and education is important to determine the exact relation between them. From a policy point of view, understanding the relationship between health and education is essential to formulate new possible policy interventions targeted to the improvement of children's status in developing countries. Given the growing importance of the potential strong connection between nutrition and schooling in developing countries the analysis presented in this work makes progress in sorting out such a casual relationship. Furthermore, investments in health is expected to have positive effects on education since the returns from investment in education last for many periods and health status is positively correlated with life expectancy. The mechanism by which health and nutrition influence educational achievement is not well established, but poor health and malnutrition in early childhood may affect cognitive abilities, necessary for learning process and consequently educational achievement. This study hopes to find out the answer to the relationship between the nutritional status of the students and its effect on their academic status and also suggest modalities of overcoming those problems performance in a sample of college students in Dharmanagar district in North Tripura which has hitherto not been documented by any worker. The study has its own set of limitations. Firstly, considering the epidemiological nature of the study, the sample size is small. Secondly, it represents only a fraction of the students of a particular college in North Tripura and thus is not suited to be extrapolated to the whole student population without undertaking a comprehensive large scale survey. Thirdly, due to paucity of funds and manpower, the researcher had to depend upon the students self provided information to the questionnaire.

\section{Literature Review}

Malnutrition is a major problem in both developed and developing countries and deficiencies in some nutrients have been reported to cause diseases which could lead to impaired cognitive development [5]. Other studies have related lifestyle of students, particularly breakfast consumption, to their cognitive abilities as reflected in their academic performance [6-8]. However, most of these studies have excluded young adults in the tertiary institution. Undernourished children have been shown to have decreased attendance, attention, and 
academic performance as well as experience more health problems compared to well-nourished children $[15,18]$. More recently, studies have examined the impact of breakfast on cognition, behavior, and academic performance of school-age children [15,19-21]. This research suggests some positive effect of breakfast on performance of specific cognitive tasks [15,20,21]. However, gaps exist in the literature examining the longterm effects of breakfast on academic performance and how the observed effects of breakfast on cognition are modified by age, sex, and nutritional status [15,21]. The single study not restricted to breakfast demonstrated a positive association between the consumption of regular meals and academic performance [22].

Most studies of health-promoting profiles of students, such as the European Health and Behavior Survey conducted in 20 countries, did not explore the associations ]between health and academic achievement [23). Indeed Al-Kandari and Vidal [24] noted that no study has yet been published on e.g., nursing students' health promoting lifestyle profiles, particularly examining their relationship with academic performance and nursing courses. Conversely, most studies of the factors associated with students' educational attainment were mainly concerned with educational and/or demographic variables and did not concurrently explore the students' health-related parameters [25]. Geographically, the majority of research conducted assessed the associations between health/health programmes and academic achievement and were undertaken in the USA [26-28], with fewer studies from the UK or elsewhere [25]. Also the associations between health/health programmes and academic attainment were mostly examined in elementary, middle or high school children [29-33], rather than university/college students [25].

The potential for health to improve cognitive function, learning and academic achievement in children has received attention by researchers and policy makers [34]. It is widely accepted that health and well-being are essential elements for effective learning [2]. Vice versa, education is a strong predictor of lifelong health and quality of life in different populations, settings, and time [35]. However, the pathways through which education leads to better health and longer life expectancy are still not clearly understood. It is widely held, however, that education, health, and social outcomes are very closely interdependent [36].

Several studies have documented the relationship between poor health, nutrition and school achievement. Low anthropometric measurements (height-for-age, weight-for height and head circumference) have been frequently associated with poor school outcomes.[2,3-6,34-36]. In fact, in several of the studies, the relationship remained significant, even after controlling for socioeconomic variables.[3-5,9]. Iron-deficiency anemia, missing breakfast and helminthic infections have also been reported to affect school performance [36,34-36]. Eating disorders create a variety of medical conditions that occur more frequently in the college-age population. [50]. For college students these conditions are key factors that may have a lasting impact not only on their academic achievements while in school, but also on their professional performances before and after graduation.

Gardner and Grantham-McGregor stated that the mechanisms which link under nutrition and poor development in children are not well understood, although children who were moderately to severely malnourished during their early childhood show delayed development [37].

Studies of nutrition and academic performance have typically focused on hunger, malnutrition, and micronutrient deficiency [38-40]. The predominant approach to studying diet has focused on the role of individual nutrients or foods [41].However; individuals do not consume single nutrients but combinations of foods [42]. In recognition of the multidimensional nature of diet, studies of the interrelations of nutrition and health have examined the effects of overall diet quality using summary measures of food and nutrient intake $[42,43]$.

Academic performance influences future educational attainment and income, which, in turn, affect health and quality of life [44]. Moreover, as increased levels of educational attainment and income facilitate increased understanding of nutrition messages and access to healthy food, [45,47] This relationship has been observed as steady across different levels of socioeconomic status [49].

College students reported $52 \%$ of the time using exercising to lose weight and $62 \%$ eating $1-2$ servings of fruit/vegetable per day [3]. Some $46 \%$ of college students reported getting enough sleep to feel rested in the morning across 3 to 5 days (Executive Summary, American College Health Association, 2011). Some 55\%, on average, of all college students report 4 or more symptoms of clinical depression (i.e. overwhelmed, sadness, hopeless, difficulty functioning) [49].

\subsection{Identification and Selection of Subjects.}

\section{Methodology}

The study was conducted on undergraduate students of Government Degree College, Dharmanagar, North Tripura. Subjects were randomly selected from across the all faculties in the campus. Subjects who had taken ill in the last 4 weeks and those currently on medication will be exempted from the study. The age group of the subjects was 19-22 years and the same was verified from their date of birth as recorded in their Madhyamik examination admit card. A total of one hundred students (58 girls and 42 boys) completed the survey from one 
hundred fifteen students selected for the survey. The subjects were explained the modalities and objectives of the study and informed oral consent were taken from the subjects as well as the principal of the college for undertaking the study.

\subsection{Anthropometric Measurements}

Recent studies [51,52] have demonstrated the applications of anthropometry to include the prediction of who will benefit from interventions, identifying social and economic inequity and evaluating responses to interventions. Height and weight of the subjects were recorded with the help of an anthrop meter and a weighing machine respectively which was calibrated every day before the start of work. All the anthropometric measurements were taken following the standard techniques recommended by Lohman etal. [53].

BMI was calculated as per WHO norms. It is calculated as the weight in kilograms divided by the square of the height in meters $(\mathrm{kg} / \mathrm{m} 2)$. BMI is age-independent and the same for both sexes [54]:

$$
\text { Body Mass Index : }=\frac{\text { Body weight in } \mathrm{kg}}{\text { Body height in } \mathrm{m}^{2}}
$$

For conducting diet survey, a minimum of three to four days of intake is generally required for characterizing usual individual intake of energy and the macronutrients [55].If enough days are collected on each individual, this could be an appropriate measure to use for research in which the individual's usual intake is the unit of interest [55]. As to how many days are needed, there has been extensive research on this topic.[55,56]. Multiple days of diet records are considered by some to be a gold standard for collection of individual dietary data. For this study and dietary survey was conducted on each individual for a period of seven days. From this data, the nutritional status of each individual was calculated with the help of food composition table [57]. Standard Diet survey questionnaire as used by National Institute of Nutrition and ICMR modified as per requirement was used in collection of data.

\section{4: Assessment of Academic Performance}

Academic performance was of the students were assessed by the marks scored by the students in the test exam conducted by the college prior to them being sent up for their university final exam. Since the students had a combination of subjects, so to bring in parity in assessment, the percentage of the total marks scored by the students were taken into consideration to rule out bias.

\section{1: Age and Sex Distribution of the Studied Population}

\section{Results}

Table:1- Age and Sex Distribution of the Studied Population:

\begin{tabular}{|c|c|c|c|c|c|c|c|}
\hline Age Range & $\begin{array}{c}\text { Tribal } \\
\text { Males }\end{array}$ & $\begin{array}{c}\text { Tribal } \\
\text { Female }\end{array}$ & $\begin{array}{c}\text { Total } \\
\text { Tribal } \\
\text { Subjects }\end{array}$ & $\begin{array}{c}\text { Non } \\
\text { Tribal } \\
\text { Males }\end{array}$ & $\begin{array}{c}\text { Non } \\
\text { Tribal } \\
\text { Females }\end{array}$ & $\begin{array}{c}\text { Total Non } \\
\text { Tribal } \\
\text { Subjects }\end{array}$ & $\begin{array}{c}\text { Grand } \\
\text { Total }\end{array}$ \\
\hline Adolescent & 27 & 15 & $\mathbf{4 2}$ & 31 & 27 & $\mathbf{5 8}$ & 100 \\
\hline
\end{tabular}

Fig 1 - Age and Sex Distribution of the Studied Population:

\section{2: Body Mass Index}

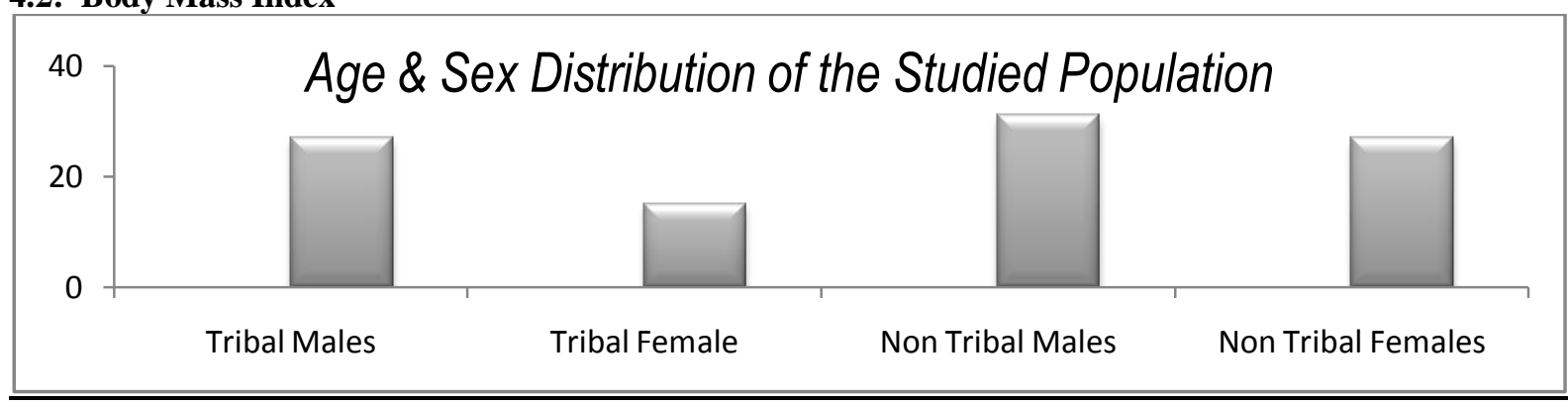

TABLE: 2 BMI OF THE SURVEYED POPULATION (MEAN VALUE)

\begin{tabular}{|c|c|}
\hline CATEGORY & BMI VALUES \\
\hline Tribal Males & 18.9 \\
\hline Tribal Females & 18.6 \\
\hline Non tribal Male & 19.2 \\
\hline Non tribal Female & 19.4 \\
\hline
\end{tabular}




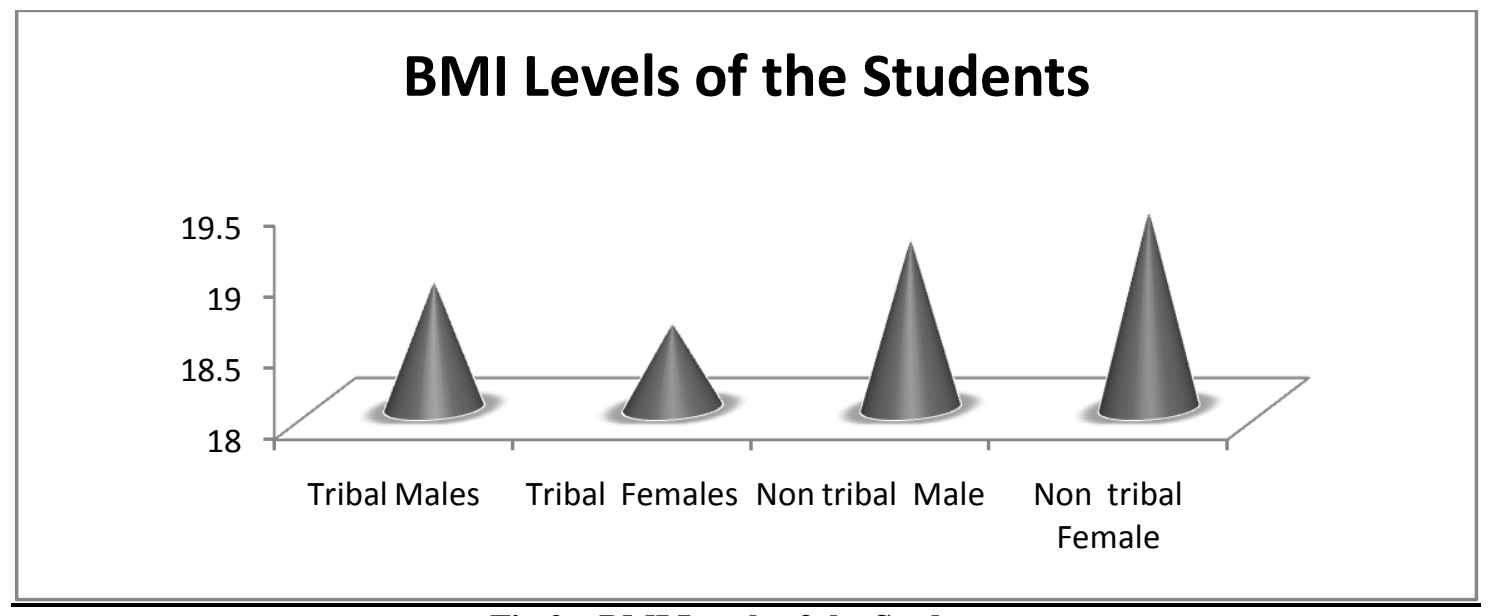

\section{Fig 2 - BMI Levels of the Students}

A study of the BMI values shows that nontribal students have a higher BMI value than their tribal counterparts, but then the BMI values shows that chronic under nutrition is not present in any of the study groups. The higher BMI levels in the nontribal students may be due to their food habit which is completely different from their tribal counterparts. While the tribal students partake of home cooked meals where they use very little of spices and mostly use boiled foods, the nontribal students seem to have an affinity for fast foods available in outlets across the town.

\subsection{Diet Survey}

Table : 3 - Food Intake of Tribal \&Non Tribal Students (Mean \pm SD)

\begin{tabular}{|c|c|c|c|c|c|c|c|c|c|c|c|}
\hline 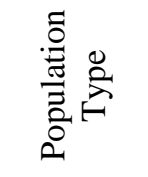 & ڤ્ & 离 & 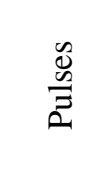 & 勇 & 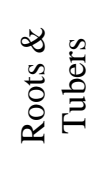 & $\begin{array}{l}\sum^{\infty} \\
\rangle_{\bar{D}}^{-} \\
\overline{0}\end{array}$ & 负 & $\begin{array}{l}\text { Milk/ } \\
\text { Milk } \\
\text { foods }\end{array}$ & $\begin{array}{l}\frac{5}{0} \\
\frac{0}{2} \\
I \\
0\end{array}$ & 氞 & 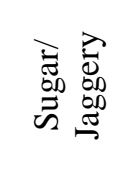 \\
\hline \multirow{2}{*}{$\begin{array}{c}\text { Tribal } \\
\text { Students }\end{array}$} & M & $\begin{array}{c}438 \pm 36 \\
.6\end{array}$ & $\begin{array}{c}13 \pm 12 \\
.8\end{array}$ & $\begin{array}{c}31 \pm 8 \\
.8\end{array}$ & $\begin{array}{c}54 \pm 9 . \\
7\end{array}$ & $\begin{array}{c}42 \pm 6 \\
.1\end{array}$ & $\begin{array}{c}18 \pm 8 \\
.3\end{array}$ & $\begin{array}{c}17 \pm 5 . \\
8\end{array}$ & $\begin{array}{c}12 \pm 6 \\
.7\end{array}$ & $6 \pm 4.4$ & $12 \pm 5.2$ \\
\hline & $\mathrm{F}$ & $\begin{array}{c}411 \pm 49 \\
.9 \\
\end{array}$ & $\begin{array}{c}12 \pm 11 \\
.1 \\
\end{array}$ & $\begin{array}{c}27 \pm 9 \\
.5 \\
\end{array}$ & $\begin{array}{c}49 \pm 12 \\
.3 \\
\end{array}$ & $\begin{array}{c}42 \pm 7 \\
.9 \\
\end{array}$ & $\begin{array}{c}12 \pm 9 \\
.9 \\
\end{array}$ & $\begin{array}{c}15 \pm 7 \\
5\end{array}$ & $\begin{array}{c}11 \pm 5 \\
.9 \\
\end{array}$ & $6 \pm 3.6$ & $12 \pm 4.7$ \\
\hline \multirow[t]{2}{*}{ RDA } & M & 420 & 60 & 100 & 100 & 100 & 100 & 500 & ----- & 25 & 35 \\
\hline & $\mathrm{F}$ & 300 & 60 & 100 & 100 & 100 & 100 & 500 & ----- & 25 & 30 \\
\hline \multirow{2}{*}{$\begin{array}{l}\% \text { of } \\
\text { RDA }\end{array}$} & M & 104 & 22 & 32 & 55 & 43 & 19 & 4 & ----- & 24 & 37 \\
\hline & $\mathrm{F}$ & 137 & 20 & 28 & 49 & 43 & 13 & 3 & P----- & 24 & 40 \\
\hline \multirow{2}{*}{$\begin{array}{c}\text { Nontriba } \\
1 \\
\text { Students }\end{array}$} & $\mathrm{M}$ & $\begin{array}{c}405 \pm 51 \\
.2\end{array}$ & $\begin{array}{c}32 \pm 15 \\
.4\end{array}$ & $\begin{array}{c}12 \pm 7 \\
.7\end{array}$ & $\begin{array}{c}31 \pm 9 . \\
9\end{array}$ & $\begin{array}{c}44 \pm 7 \\
.4\end{array}$ & $\begin{array}{c}35 \pm 4 \\
.5\end{array}$ & $\begin{array}{c}65 \pm 9 . \\
1\end{array}$ & $\begin{array}{c}22 \pm 3 \\
.3\end{array}$ & $\begin{array}{c}11 \pm 2 . \\
2\end{array}$ & $19 \pm 3.8$ \\
\hline & $\mathrm{F}$ & $\begin{array}{c}399 \pm 47 \\
.1 \\
\end{array}$ & $\begin{array}{c}26 \pm 10 \\
.9\end{array}$ & $\begin{array}{c}16 \pm 9 \\
.2 \\
\end{array}$ & $\begin{array}{c}35 \pm 10 \\
.2 \\
\end{array}$ & $\begin{array}{c}44 \pm 6 \\
.4 \\
\end{array}$ & $\begin{array}{c}16 \pm 2 \\
.8\end{array}$ & $\begin{array}{c}56 \pm 8 . \\
6\end{array}$ & $\begin{array}{c}18 \pm 4 \\
.5 \\
\end{array}$ & $9 \pm 5.1$ & $18 \pm 4.3$ \\
\hline \multirow[t]{2}{*}{$\mathrm{RDA}$} & $\mathrm{M}$ & 420 & 60 & 100 & 100 & 100 & 100 & 500 & ----- & 25 & 35 \\
\hline & $\bar{F}$ & 300 & 60 & 100 & 100 & 100 & 100 & 500 & ----- & 25 & 30 \\
\hline$\%$ of & $\mathrm{M}$ & 97 & 53 & 13 & 32 & 47 & 35 & 13 & ----- & 44 & 54 \\
\hline RDA & $\mathrm{F}$ & 133 & 43 & 17 & 35 & 44 & 16 & 11 & ------ & 36 & 60 \\
\hline
\end{tabular}




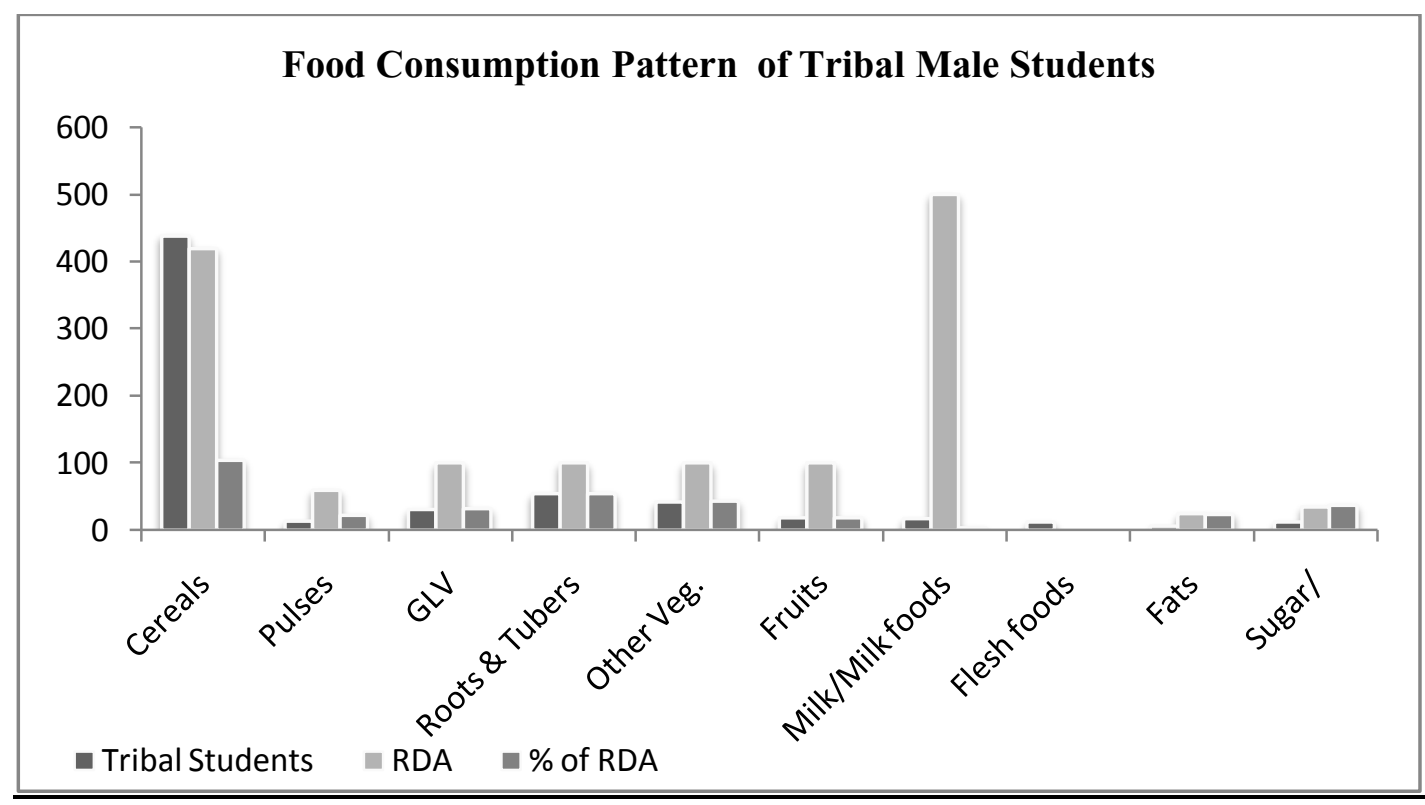

Fig 3 - Food Consumption Pattern of Tribal Male Students

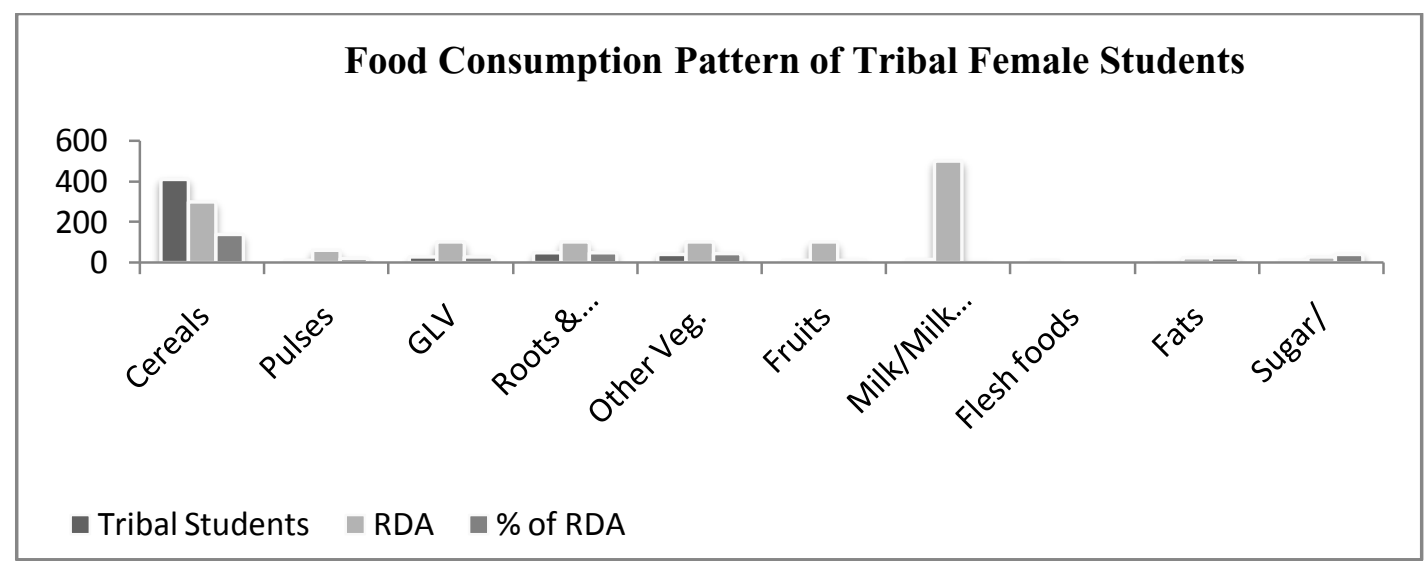

Fig 4 - Food Consumption Pattern of Tribal Female Students

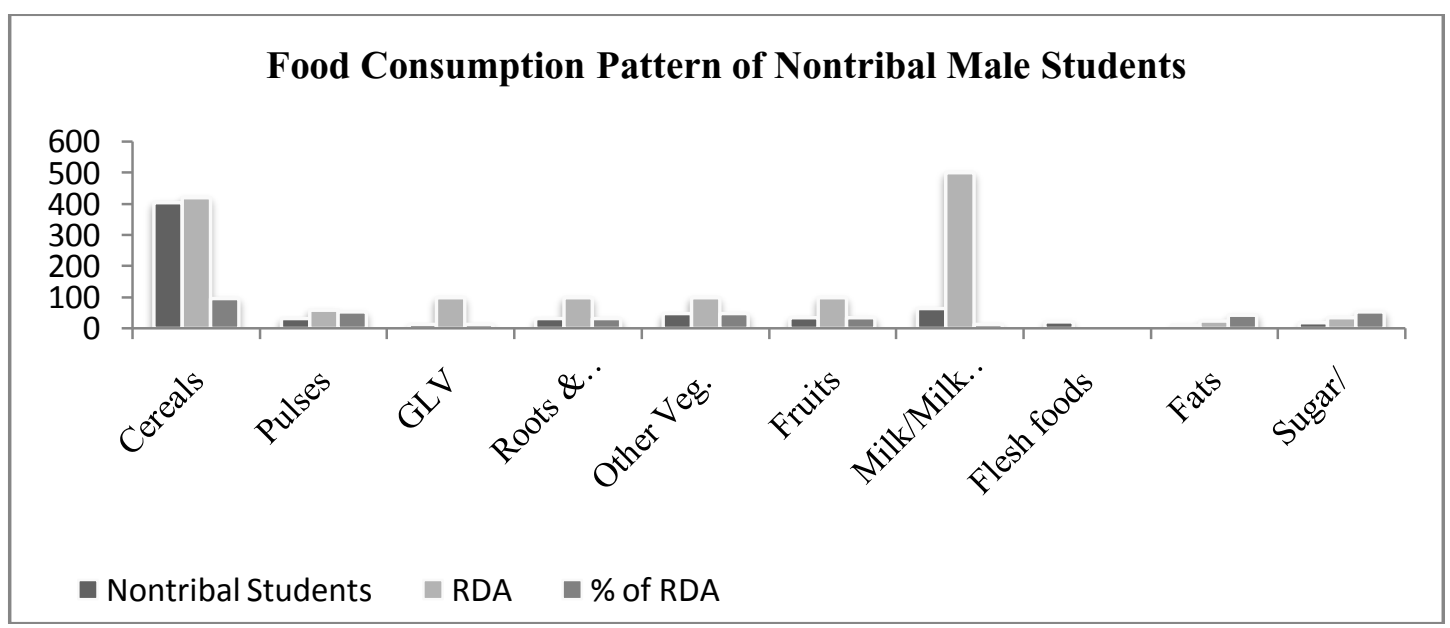




\section{Food Consumption Pattern of Nontribal Female Students}

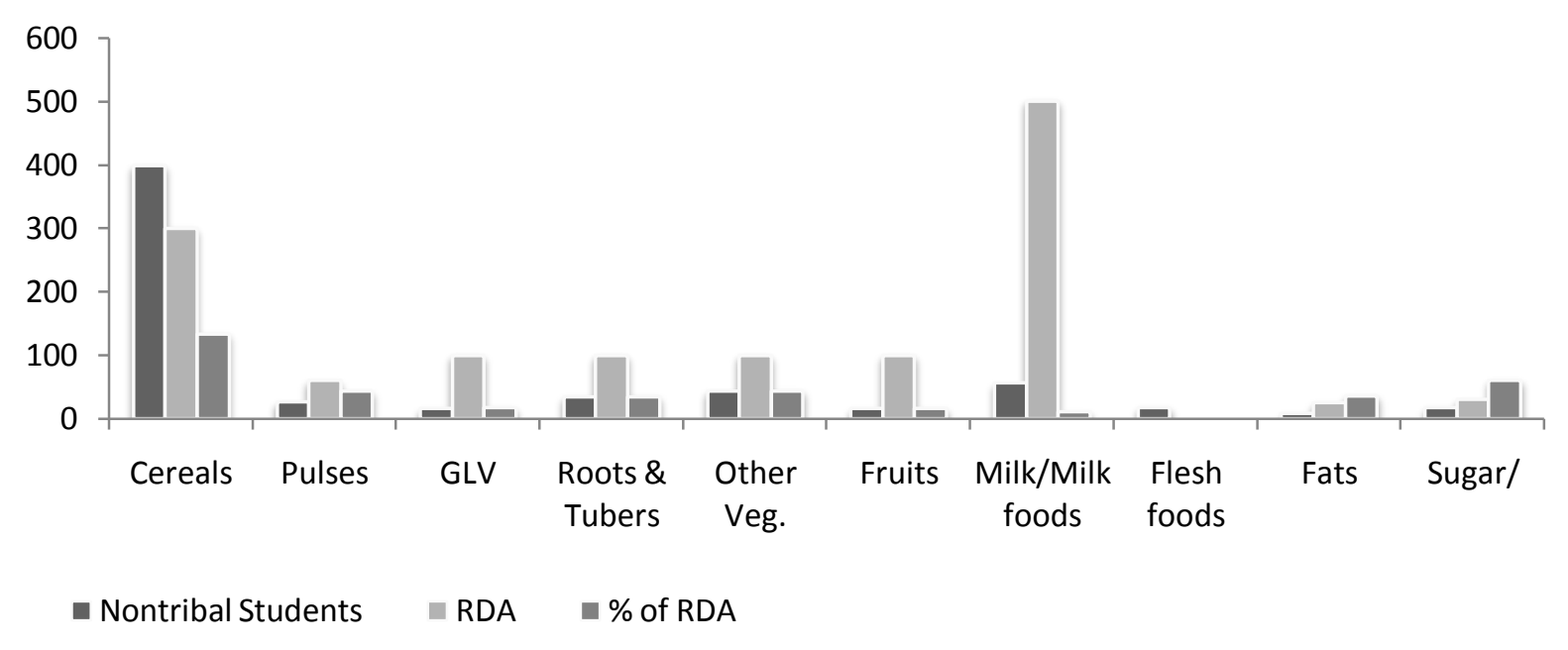

\section{Fig 6 - Food Consumption Pattern of Nontribal Female Students}

From the food composition table and the graphs, it is clear that tribal students take in more of cereals, green leafy vegetables, roots and tubers. Their consumption of fats, flesh foods and fruits are minimum .This may be due to the higher cost associated with these food groups which they can ill afford. On the other hand the non tribal students take in fewer amounts of vegetables, but compensate this with a higher consumption of fruits. The consumption of milk is also quiet high in this population. They also take in a lot of flesh foods along with higher amounts of fats and sugar. This may also be the causative factor for the higher BMI levels seen in this group. As to how these food consumption pattern translates into nutrient intake is given in the following tables.

TABLE: 4- NUTRIENT INTAKE OF TRIBAL \& NON TRIBAL STUDENTS (MEAN)

\begin{tabular}{|c|c|c|c|c|c|c|c|c|c|c|c|}
\hline 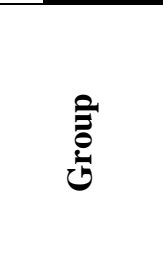 & ڤ̆ & 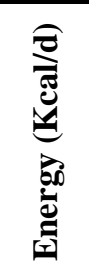 & 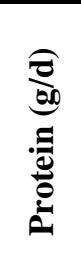 & & 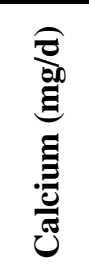 & 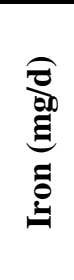 & 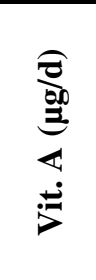 & 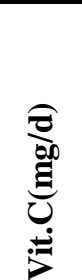 & 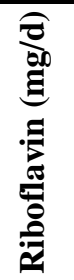 & 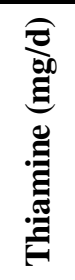 & 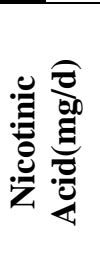 \\
\hline \multirow{2}{*}{$\begin{array}{l}\text { Tribal } \\
\text { Students }\end{array}$} & $\mathrm{M}$ & 3245 & 55.2 & 18.4 & 765.9 & 25 & 789.6 & 78.5 & 2.1 & 1.4 & 18.1 \\
\hline & $\mathrm{F}$ & 2569 & 51.2 & 15.1 & 654 & 28.5 & 732.1 & 76.3 & 1.7 & 1.6 & 16 \\
\hline \multirow[b]{2}{*}{ RDA } & M & 3017 & 61.5 & 25 & 800 & 28 & 600 & 50 & 1.8 & 1.5 & 17 \\
\hline & $\mathrm{F}$ & 2070 & 52.1 & 25 & 700 & 26 & 600 & 50 & 1.2 & 1 & 14 \\
\hline \multirow{2}{*}{$\%$ of RDA } & $\mathrm{M}$ & 108 & 90 & 74 & 96 & 89 & 132 & 157 & 117 & 93 & 106 \\
\hline & $\mathrm{F}$ & 124 & 98 & 60 & 93 & 110 & 122 & 153 & 142 & 160 & 114 \\
\hline \multirow{2}{*}{$\begin{array}{l}\text { Nontribal } \\
\text { Students }\end{array}$} & M & 2554 & 45.3 & 124 & 447 & 19.8 & 412 & 65.4 & 1.3 & 0.87 & 15.1 \\
\hline & $\mathrm{F}$ & 1876 & 37.2 & 94 & 385 & 15.3 & 358 & 66.8 & 1.2 & 0.78 & 12.2 \\
\hline \multirow[b]{2}{*}{ RDA } & M & 3017 & 61.5 & 94 & 800 & 28 & 600 & 50 & 1.1 & 1.5 & 17 \\
\hline & $\mathrm{F}$ & 2070 & 52.1 & 99 & 700 & 26 & 600 & 50 & 1.2 & 1 & 14 \\
\hline \multirow{2}{*}{$\%$ of RDA } & $\mathrm{M}$ & 85 & 74 & 132 & 56 & 71 & 69 & 131 & 118 & 58 & 89 \\
\hline & $\mathrm{F}$ & 91 & 71 & 95 & 55 & 59 & 60 & 134 & 100 & 78 & 87 \\
\hline
\end{tabular}




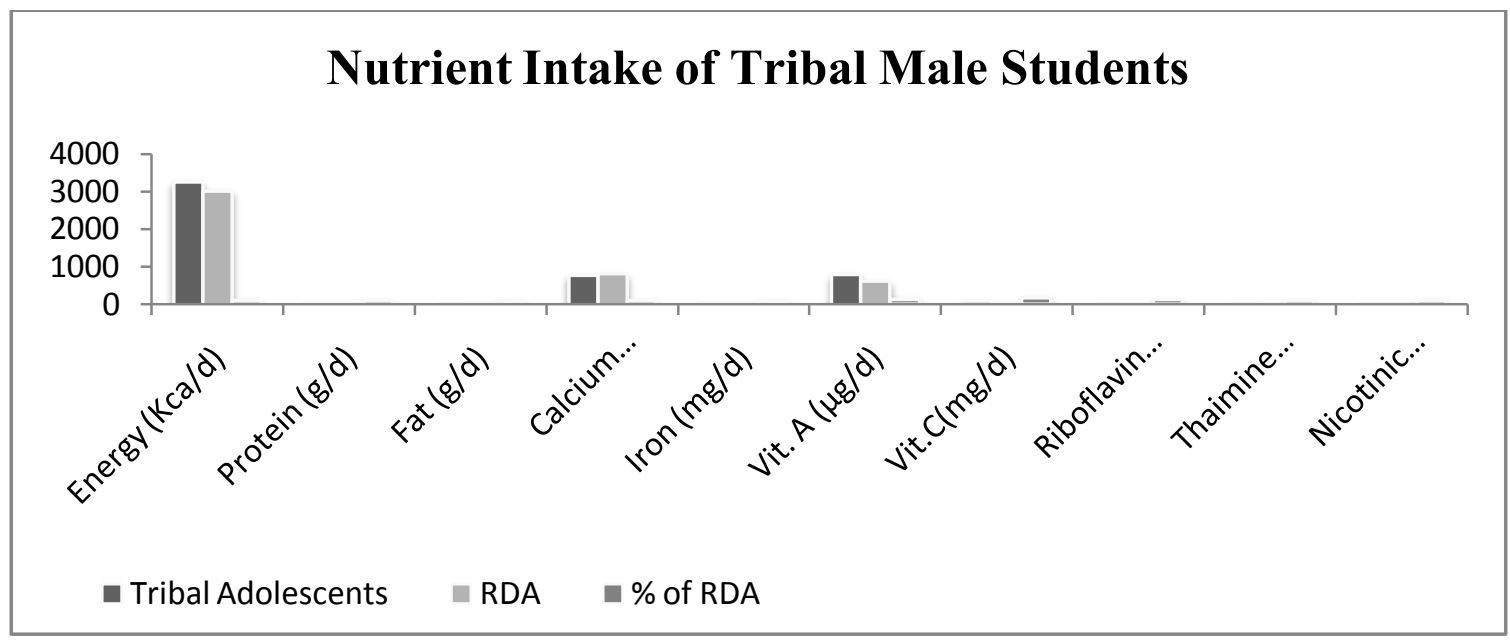

Fig 7 - Nutrient Intake of Tribal Male Students

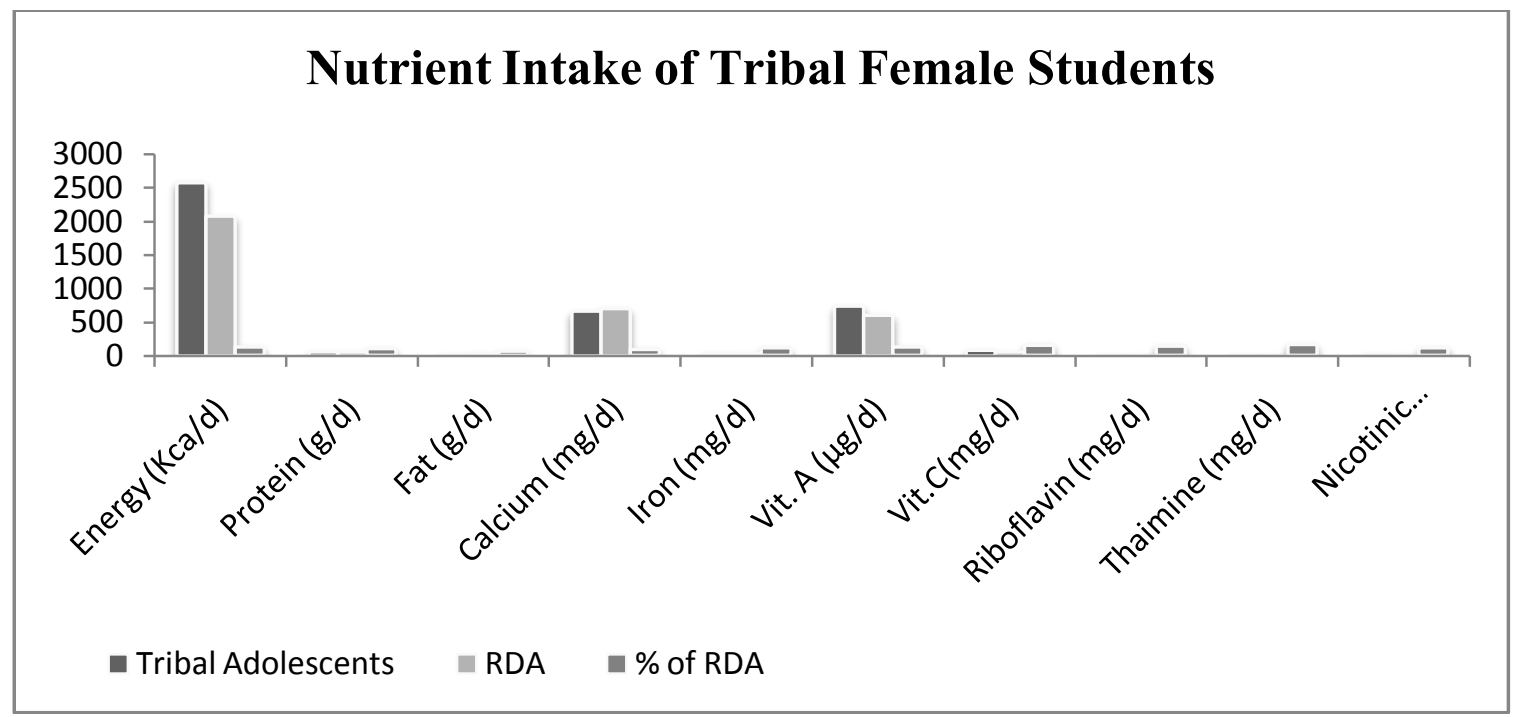

$\underline{\text { Fig } 8 \text { - Nutrient Intake of Tribal Female Students }}$

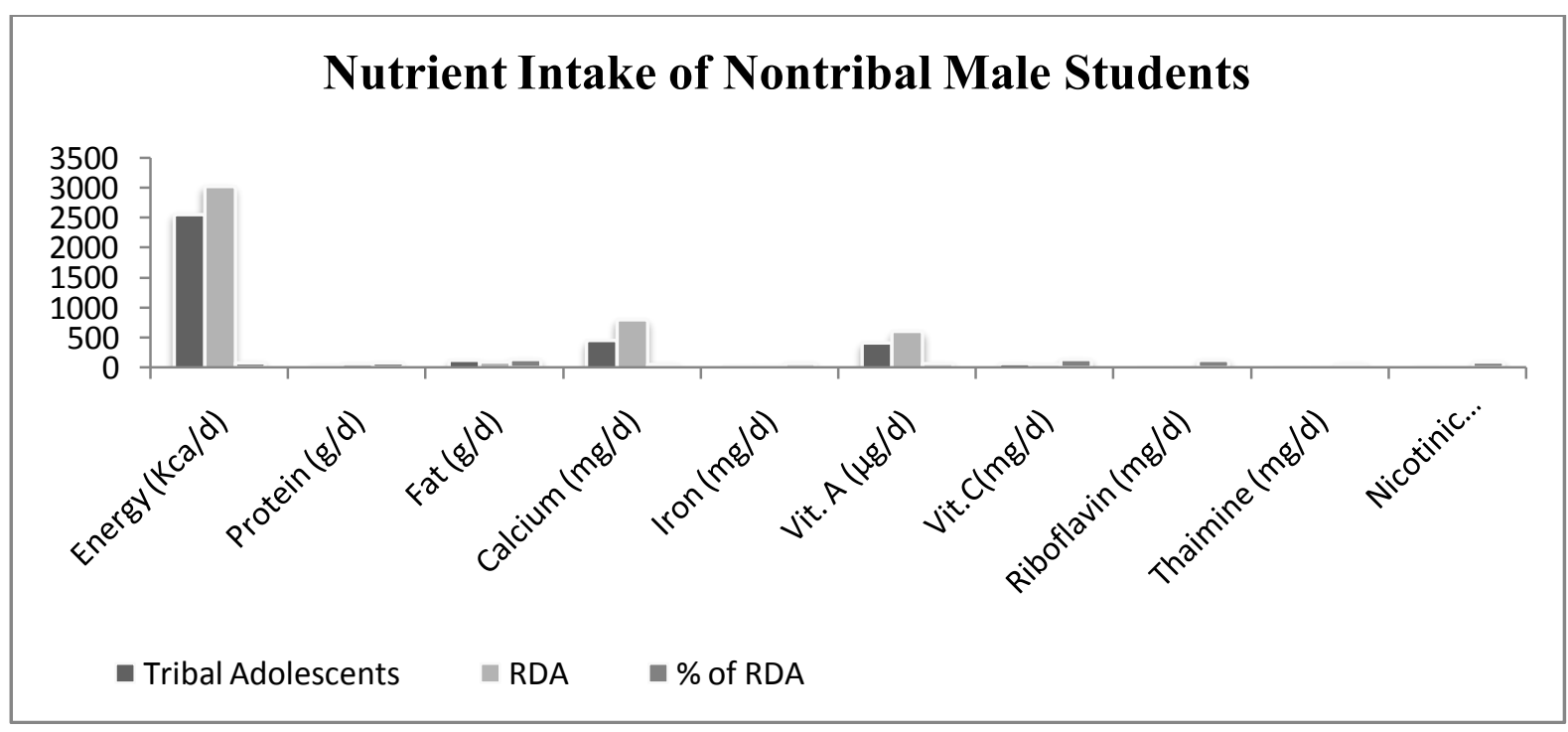




\section{Fig 9- Nutrient Intake of Nontribal Male Students}

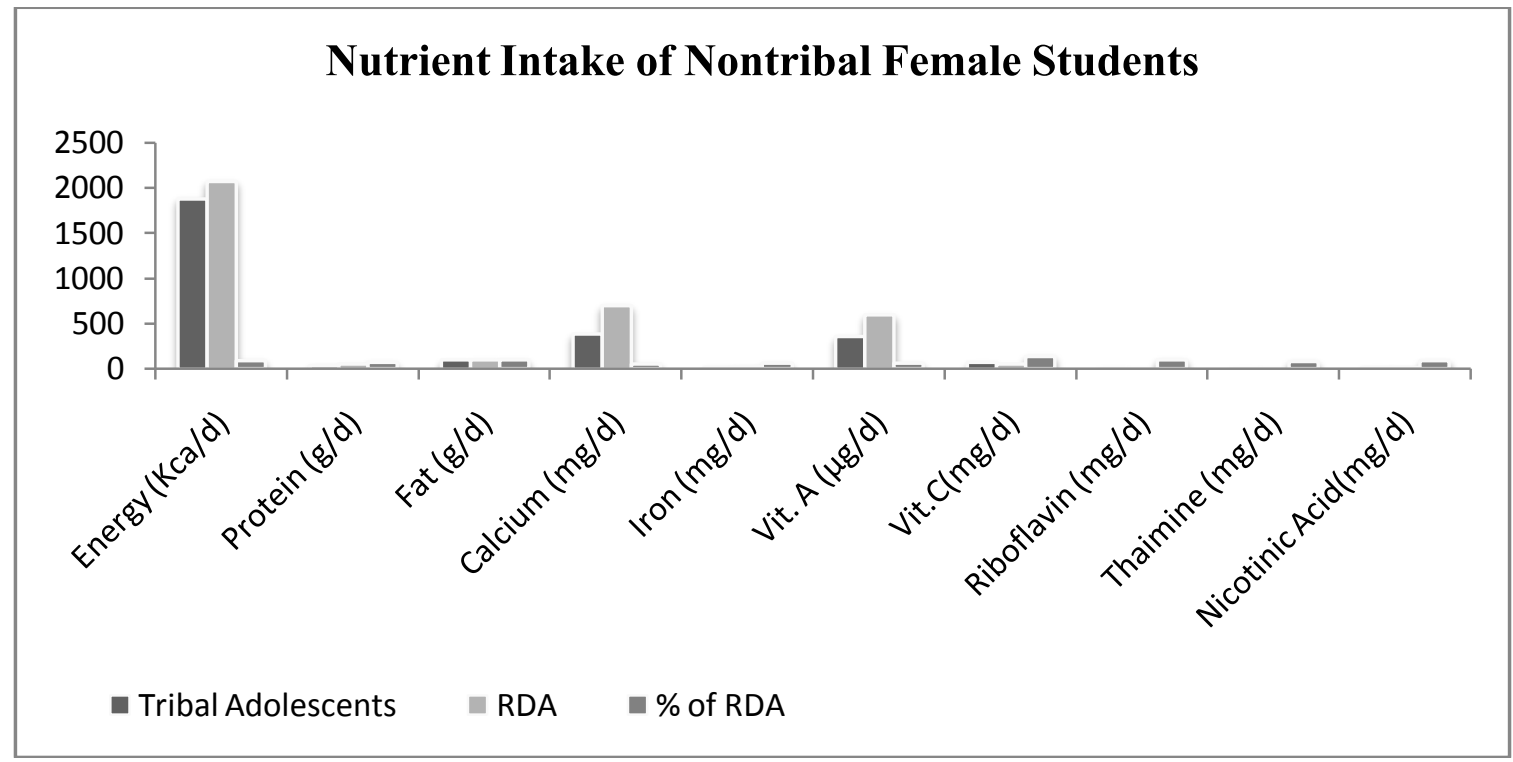

Fig 10 - Nutrient Intake of Nontribal Female Students

Thus the nutrient consumption table shows that the energy consumption of tribal students is slightly higher, but a major difference exists in the energy availability in the female students. While tribal female students have adequate energy consumption, the nontribal populace suffers from deficient energy consumption. This may due to food fads in females and also the influence of television or peer pressure to remain thin. The protein consumption levels are almost similar but fat intake is very less in the nontribal group. But then the levels of consumption of other minerals like calcium, iron and those of various vitamins are quiet high in the tribal group than in the nontribal population. This may be due to the intake of more of vegetables in the tribal group than the nontribal students.

\subsection{Academic Status}

TABLE: 5- Category wise Percentage Achievement

\begin{tabular}{|c|c|c|c|c|c|c|}
\hline Category & $<20$ & $21-30$ & $31-40$ & $41-50$ & $51-60$ & $>60$ \\
\hline Tribal Male & 2 & 6 & 11 & 4 & 2 & 2 \\
\hline Tribal Female & 3 & 4 & 4 & 3 & 1 & Nil \\
\hline Nontribal Male & 10 & 11 & 7 & 1 & 2 & Nil \\
\hline Nontribal Female & 4 & 10 & 6 & 3 & 3 & 1 \\
\hline
\end{tabular}

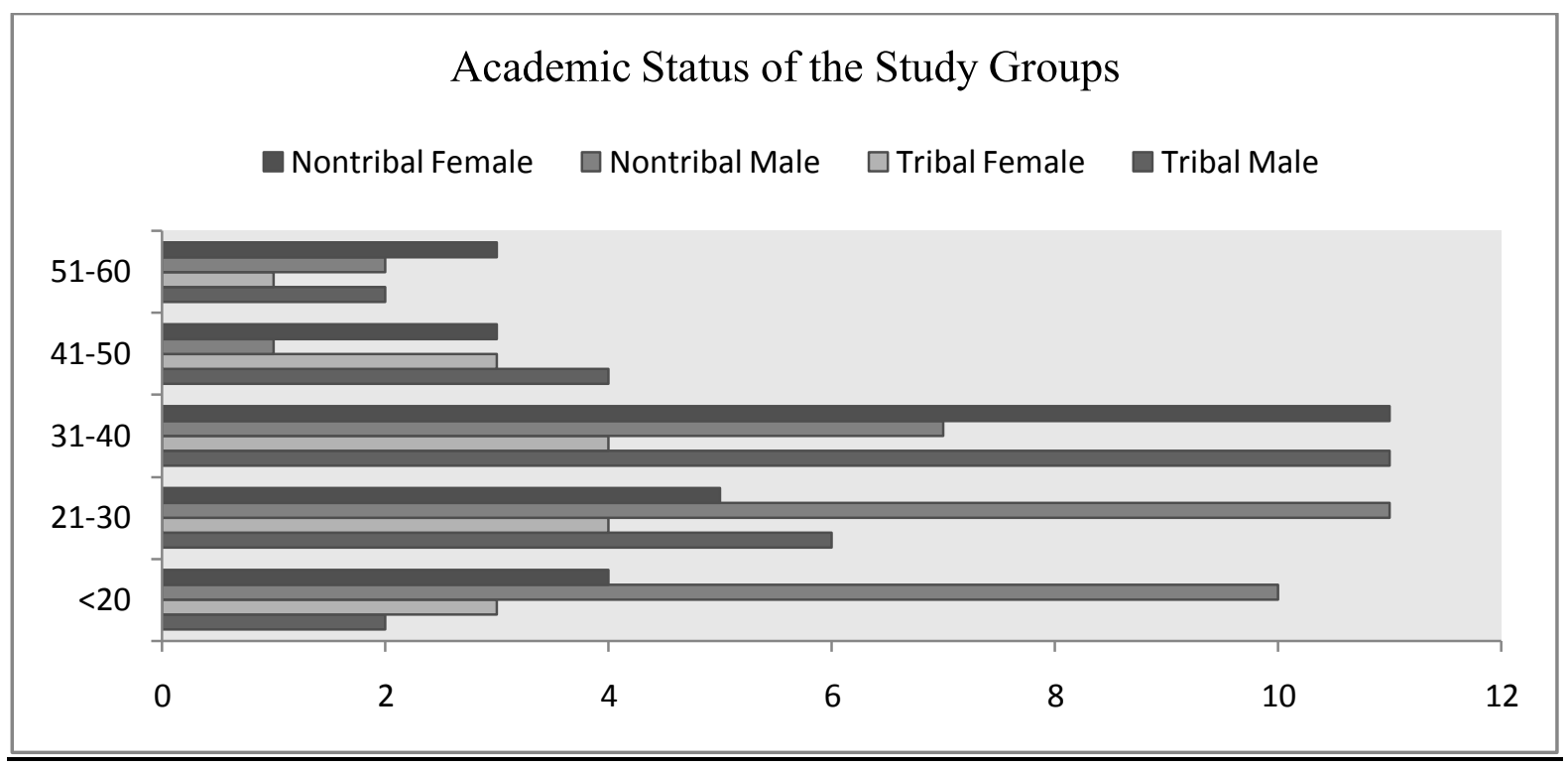


Fig 11 - Academic Status of the Study Groups

TABLE: 6 Category wise Average Marks Obtained

\begin{tabular}{|c|c|c|c|c|}
\hline Category & Tribal Male & Tribal Female & Nontribal Male & $\begin{array}{c}\text { Nontribal } \\
\text { Female }\end{array}$ \\
\hline$<20$ & 13 & 14 & 10 & 13 \\
\hline $21-30$ & 24 & 26 & 22 & 23 \\
\hline $31-40$ & 34 & 46 & 39 & 42 \\
\hline $41-50$ & 42 & 45 & 44 & 47 \\
\hline $51-60$ & 51 & 58 & 54 & 51 \\
\hline$>60$ & 63 & Nil & Nil & 64 \\
\hline
\end{tabular}

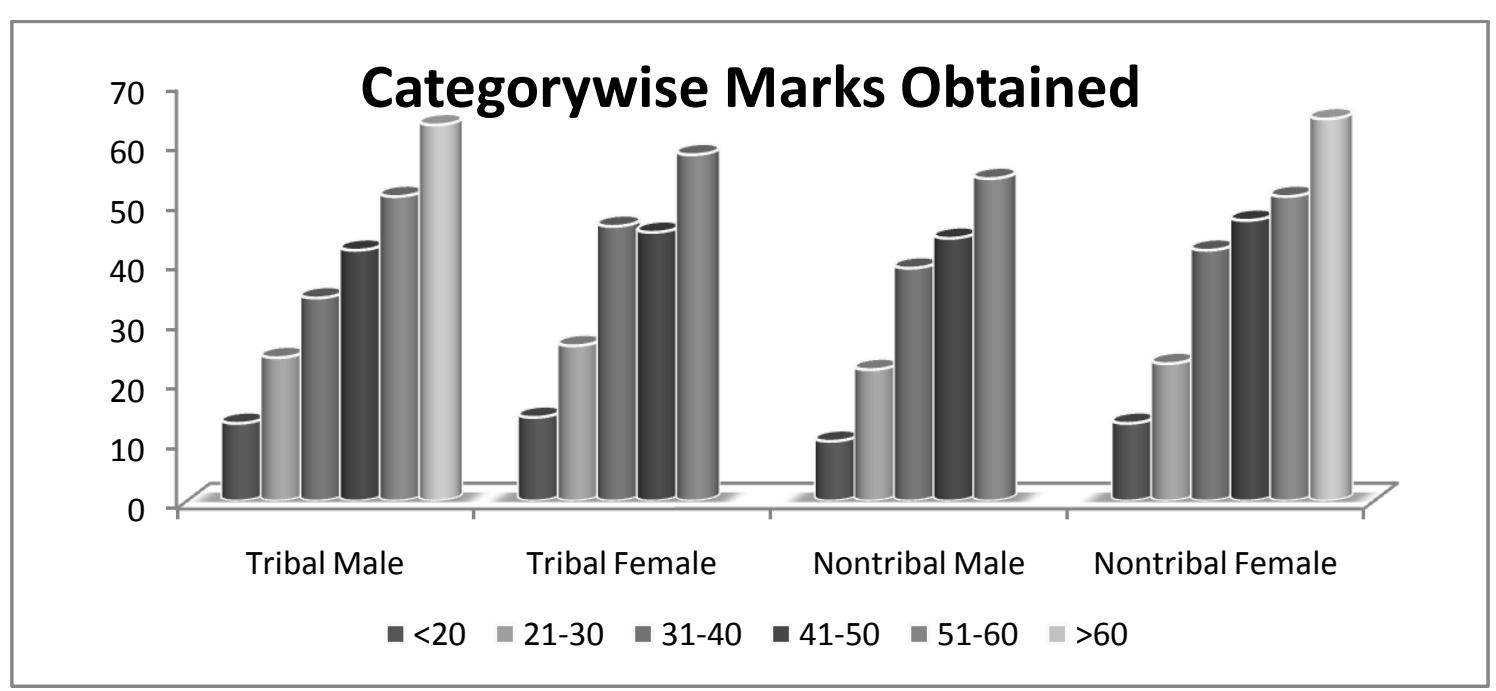

Fig 12 - Category wise Average Marks Obtained

The data from the study was analyzed with the help of SPSS (version-10) software to find out the correlation between academic status of the students of the study group and the various factors, and also to develop regression equations to understand the degree of association between the various variables that affect the academic status of these students. They are detailed below:

i) The correlation coefficient between BMI and academic status was found to be 0.236 ( $\mathrm{R}$ square value at 0.005 level of significance). Thus BMI levels are negatively correlated, albeit weakly with academic achievement.

The relationship can be better explained with the help of the following linear regression equation :

$$
\begin{aligned}
& E=159.92-0.486 \mathrm{~B} \\
& \mathrm{SE}(162.893) \quad(8.561),
\end{aligned}
$$

Where, $\mathrm{E}=$ Academic Status of the study group, $\mathrm{B}=\mathrm{BMI}$ of the study group and $\mathrm{SE}=$ standard error of estimate.

ii) The correlation coefficient between Energy consumption and academic status was found to be 0.025 ( $R$ square value at 0.005 level of significance).This denotes a weak but positive correlation between Energy consumption and academic status of the study group. The relationship can be better explained with the help of the following linear regression equation :

$$
\begin{aligned}
& \mathrm{E}=28.349+0.158 \mathrm{EC} \\
& \mathrm{SE} \quad(15.786) \quad(0.006),
\end{aligned}
$$

Where, $\mathrm{E}=$ Academic Status of the study group, $\mathrm{EC}=$ Energy consumption of the study group and $\mathrm{SE}=$ standard error of estimate.

iii) The correlation coefficient between Protein intake and academic status was found to be 0.109 ( $\mathrm{R}$ square value at 0.005 level of significance).This denotes a weak positive correlation between Protein intake and academic status of the study group. The relationship can be better explained with the help of the following linear regression equation : 


$$
\begin{aligned}
& \mathrm{E}=22.191+0.330 \mathrm{P} \\
& \mathrm{SE} \quad(19.734) \quad(0.414),
\end{aligned}
$$

Where, $\mathrm{E}=$ Academic Status of the study group, $\mathrm{P}=$ Protein intake of the study group and $\mathrm{SE}=$ standard error of estimate.

\section{Conclusion}

The above study shows that that, firstly, the tribal students have lower BMI values than their nontribal counterparts which may be due to dietary differences - tribal students have less access to convenience foods and as such may have less consumption of these type of empty calorie containing foods. Also the academic achievements of tribal students are a little lower than their nontribal counterparts which again come out in the regression and negative correlation of BMI with academic achievement.

The dietary survey shows that tribal students take in more of cereals, green leafy vegetables, roots and tubers. Their consumption of fats, flesh foods and fruits are minimum. This may be due to the higher cost associated with these food groups which they can ill afford. When these dietary survey data are converted to energy and nutrient consumption with the help of food composition tables it is seen that the energy consumption of tribal students is slightly higher, but a major difference exists in the energy availability in the female students. While tribal female students have adequate energy consumption, the nontribal populace suffers from deficient energy consumption. Consumption of other minerals like calcium, iron and those of various vitamins are also quiet high in the tribal group. Statistical analysis of these nutrients consumption data with that of their academic achievement provides valuable insight into the role of various nutrients in academic achievement of these students. It was found that BMI and fat consumption levels are negatively correlated with academic achievement. Though the correlation of BMI with academic achievement is weak, fat consumption is strongly correlated with academic achievement. This may be due to the fact that fats form a crucial part of the neuronal circuitry. All other nutrients are positively correlated with academic excellence. Of the various vitamins, Vitamin $\mathrm{C}$ has the strongest correlation with academic status, followed by Vitamin A Riboflavin and Thiamine respectively. This correlation may be because, all these vitamins are particularly important for neuronal development as well as neuronal connectivity and signal processing and transmission.

Thus from the above study and analysis of the data generated, we can conclude that nutritional status of a college student has definite relationship with his/her academic achievement.

\section{Reference}

[1]. Pollitt, E., Nutrition and Educational Achievement. Nutritional Education Series, 1984; Issue 9. ED84/WS/66. UNESCO, Paris

[2]. Popkin BM, Lim-Ybanez M. Nutrition and school achievement.SocSci Med 1982; 16: 53-61.

[3]. Jamison DT. Child malnutrition and school performance in China.J Dev Econ 1986; 20: 299-309.

[4]. Moock PR, Leslie J. Childhood malnutrition and schooling in the Terai region of Nepal. J Dev Econ 1986; 20: 33-52.

[5]. Johnston FE, Low SM, Baessa YD, MacVean RB. Interaction of nutritional and socioeconomic status as determinants of cognitive development in disadvantaged urban Guatemalan children. Am J Phy. Anthropol 1987; 73: 501-506.

[6]. Sigman M, Neumann C. Cognitive abilities of Kenyan children in relation to nutrition, family characteristics and education. Child Dev 1989; 60: 1463-1474.

[7]. Pollit E, Watkins WE, Husaini MA, Three month nutritional supplementation in Indonesia infants and toddlers, benefit child memory function 8years later. Am. J. Clin. Nutr.1997; 66: 1357-1363.

[8]. Lisa MS , The correlation between eating breakfast and school performance. Am .J. Clin Nutr.1998; 65: 7795-9845.

[9]. World Health Organization, Young people's health. a challenge for society; report of a WHO Study Group on Young People and Health for All by the Year 2000. Geneva: World Health Organization. Technical Report, 1986; Series No. 731, 1-117.

[10]. Matsuhashi Y., Thinness: drives and results. J. Adolesc. Health.2000; 27: 149-150.

[11]. 11. Ryan YM, Gibney MJ, Flynn MA, The pursuit of thinness: a study of Dublin schoolgirls aged $15 \mathrm{y}$. Int. J. Obes. Relat. Metab. Disord1998;.22:485-487.

[12]. Thompson AM, Chad KE ,The relationship of social physique anxiety to risk for developing an eating disorder in young females. J. Adolesc. Health.2003; 31: 183-189.;

[13]. Jones JM, Bennett S, Olmsted MP, Lawson ML, Rodin G ,Disordered eating attitudes and behaviours in teenaged girls: a school-based study. Can. Med. Assoc. J.2001; 165: 547-552.;

[14]. Weinshenker, Adolescence and body image. School Nurse News.2002; 19:12-16.

[15]. Taras H. Nutrition and student performance at school. J Sch Health. 2005;75:199-213. 
[16]. Galal O, Hulett J. The relationship between nutrition and children's educational performance: a focus on the United Arab Emirates. Nutr Bull. 2003;28:11-20.

[17]. Kretchmer N, Beard JL, Carlson S. The role of nutrition in the development of normal cognition. Am J Clin Nutr. 1996;63(suppl 1):997-1001.

[18]. Meyers AF, Sampson AE, Weitzman M. Nutrition and academic performance in school children. Clin Appl Nutr. 1991;1:13-25.

[19]. Kleinman RE, Hall S, Green H, et al. Diet, breakfast and academic performance in children. Ann Nutr Metab. 2002;46(suppl 1):24-30.

[20]. Rampersaud GC, Pereira MA, Girard BL, et al. Breakfast habits, nutritional status, body weight, and academic performance in children and adolescents. J Am Diet Assoc. 2005;105:743-760.

[21]. Pollitt P, Matthews R. Breakfast and cognition: an integrative summary. Am J Clin Nutr. 1998;67(suppl 1):804-813.

[22]. Kim HY, Frongillo EA, Han SS, et al. Academic performance of Korean children is associated with dietary behaviours and physical status. Asia Pac J Clin Nutr. 2003;12(2):186-192.

[23]. Wardle J, Steptoe A. The European Health and Behavior Survey: Rationale, Methods and Initial Results for the United Kingdom. Soc. Sci. Med. 1991;33:925-936. 24) Al-Kandari F, Vidal VL. Correlation of the Health-Promoting Lifestyle, Enrollment Level, and Academic Performance of College of Nursing Students in Kuwait. Nurs. Health Sciences. 2007;9:112-119.

[24]. Hoskins SL, Newstead SE, Dennis I. Degree Performance as a Function of Age, Gender, Prior Qualifications and Discipline Studied. Assess. Eval. Higher Educ. 1997;22:317-328.

[25]. Elias MJ, Gara MA, Schuyler TF, Branden-Muller LR, Sayette MA. The Promotion of Social Competence: Longitudinal Study of a Preventive School-Based Program. Am. J. Orthopsychiatr. 1991;61:409-417.

[26]. McCord MT, Klein JD, Foy JM, Fothergill K. School-Based Clinic Use and School Performance. J. Adolesc. Health. 1993;14:91-98.

[27]. Eggert LL, Thompson EA, Herting JR, Nicholas LJ, Dicker BG. Preventing Adolescent Drug Abuse and High School Dropout through an Intensive School-Based Social Network Development Program. Am. J. Health Promot. 1994;8:202-215.

[28]. Keeley TJH, Fox KR. The Impact of Physical Activity and Fitness on Academic Achievement and Cognitive Performance in Children. Int. Rev. Sport Exerc. Psychol. 2009;2:198-214.

[29]. Felner RD, Jackson AW, Kasak D, Mulhall P, Brand S, Flowers N. The Impact of School Reform for the Middle Years. Phi Delta Kappan. 1997;78:528-532.

[30]. Meyers AF, Sampson AE, Weitzman M, Rogers BL, Kayne H. School Breakfast Program and School Performance. Am. J. Dis. Child. 1989;143:1234-1239.

[31]. Gall G, Pagano ME, Desmond MS, Perrin JM, Murphy JM. Utility of Psychosocial Screening at a SchoolBased Health Center. J. School Health. 2000;70:292-298.

[32]. Flay B, Allred CG, Ordway C. Effects of the Positive Action Program on Achievement and Discipline: Two Matched-Control Comparisons. Prev. Sci. 2001;2:71-89.

[33]. Ivanovic D, Marambio M. Nutrition and education. I. Educational achievement and anthropometric parameters of Chilean elementary and high school graduates. Nutr Rep Intl 1989; 39: 983-993.

[34]. Keeley TJH, Fox KR. The Impact of Physical Activity and Fitness on Academic Achievement and Cognitive Performance in Children. Int. Rev. Sport Exerc. Psychol. 2009;2:198-214.

[35]. Kolbe LJ. Education Reform and the Goals of Modern School Health Programs. Educ. Stand. 2002;3:411.

[36]. Gardner JM, Grantham-McGregor S. Activity levels and maternalchild behavior in under nutrition: Studies in Jamaica. In: Pan American Health Organization Nutrition, Health and Child Development Scientific Publication No 566 Washington, DC PAHO, 1998: 32-42.

[37]. Taras H. Nutrition and student performance at school. J Sch Health. 2005;75:199-213.

[38]. Galal O, Hulett J. The relationship between nutrition and children's educational performance: a focus on the United Arab Emirates. Nutr Bull. 2003;28:11-20.

[39]. Kretchmer N, Beard JL, Carlson S. The role of nutrition in the development of normal cognition. Am J ClinNutr. 1996;63(suppl 1):997-1001.

[40]. Gerber M. The comprehensive approach to diet: a critical review. J Nutr. 2001;131(suppl 11):3051-3055.

[41]. Kant AK. Indexes of overall diet quality: a review. J Am Diet Assoc. 1996;96:785-791.

[42]. Patterson RE, Haines PS, PopkinBM. Diet quality index: capturing a multidimensional behavior. J Am Diet Assoc. 1994;94:57-64.

[43]. Ross CE, Wu C. The links between education and health. Am Sociol Rev. 1995;60:719-745.

[44]. Veugelers PJ, Fitzgerald AL. Dietary intake and risk factors for poor diet quality among children in Nova Scotia. Can J Public Health. 2005;96:212-216. 
[45]. Kant AK. Consumption of energy-dense, nutrient-poor foods by adult Americans: nutritional and health implications: the third national health and nutrition examination survey, 1988-1994.Am J ClinNutr. 2000;72:929-936.

[46]. Turrell G, Hewitt B, Patterson C, et al. Measuring socio-economic position in dietary research: is choice of socio-economic indicator important? Public Health Nutr. 2003;6:191-200.

[47]. Baranowski T, Mendlein J, Resnicow K, et al. Physical activity and nutrition in children and youth: an overview of obesity prevention. Prev Med. 2000;31(suppl 1):1-10.

[48]. Considine G, Zappala G. The influence of social and economic disadvantage in the academic performance of school students in Australia.J Sociol. 2002;38:129-148.

[49]. Grace, T.W., 1997. Health problems of college students. worsened after joining the university. J. Am. College Health, 45: 243-250.

[50]. Physical status: the use and interpretation of anthropometry. World Health Organ Tech Rep Series, 854, 1995. http://www.who.int/ bmi/index.jsp?introPage=intro_6.html as on 7th June, 2007.

[51]. Rao G, Yadav R, Dolla C K, Kumar S, Bhondeley M K,Ukey M, Under nutrition \& childhood morbidities among tribal preschool children, Indian J Med Res 122 (2005) 43.

[52]. Lohman, T G, Roche A F, Martorell R, Anthropometric Standardization Reference Manual, Human Kinetics Books, Chicago, (1998) 75.

[53]. World Health Organization. Measuring change in nutritional status. Geneva: World Health Organization, 1983, 64.

[54]. Hartman A. M, Block G. Dietary assessment methods for macronutrients. In: Micozzi MS, Moon TE, Eds. Macronutrients Investigating their Role in Cancer. New York Marcel Dekker, Inc. 1992; 87-124.

[55]. Block G. A review of validations of dietary assessment methods. Am J Epidemiol 1982; 115:492-505.

[56]. Gopalan C, B V Ramasastri, S C Balasubramaniam, Nutritive value of Indian Foods, Hyderabad, 2004. 